\title{
Empowering Others: Motives and Strategies Successful Ghanaian Women Adopt
}

\author{
DORIS ABENA AKYERE BOATENG \\ University of Ghana, Ghana
}

KWAKU OSEI-HWEDIE
University of Ghana, Ghana

I believe that it is up to us women to create the spaces that will empower other women. We have been side-lined for far too long...so it is about time we got up to fight for our fellow women (Study participant).

\begin{abstract}
This paper discusses the ways in which successful Ghanaian women seek to empower other women. It is important to explore this issue because literature on social change has mainly focused on the macro level social movements with little attention to the micro factors. Using a qualitative research design, 30 participants were purposively selected from academia, politics and trade for in-depth interviewing. The study revealed that in seeking to empower other women, successful women employ strategies such as mentorship, active participation in their communities, pushing for female-friendly work policies and advocating for youth development. In the post 2015 development agenda, attention must be paid to providing women with increased opportunities to empower other women at the micro level. These findings offer insights for social workers, policy makers, and future researchers.
\end{abstract}

\section{Keywords}

gender role, migrant families, educational empowerment

\section{Introduction}

In many development dialogues, empowerment is used to mean different things. Batliwala (2007: 557) argues that "empowerment is probably the most widely used and abused" word in development practice. Perhaps due to its historical roots in social justice and the redistribution of power such that communities are able to pursue their own developmental needs; the term empowerment has often taken a macro level approach. In many instances, when governments pursue empowerment programmes they are geared towards movements such as pro-life or pro-choice; or at opening up access for citizens to participate in civic activities and decision-making.

In an earlier work that examined the concept, Rowlands (1995) highlights the different meanings of empowerment in a variety of socio-developmental contexts. Among her most cogent arguments is that "empowerment is more than simply opening up access to decision making but also includes the processes that lead people to perceive themselves as able and entitled to occupy that decision-making space" (102). While it is important to pursue 
macro level development and empowerment processes, no government can attain complete development if it does not pay attention to how its members can also be empowered at the micro level.

For many decades, issues and discourses about women from developing countries and the global south have focused on their challenges and deficits, without a commensurate attention paid to their successes and triumphs. In many instances, women are categorised as a weak unit in need of rescuing, irrespective of their achievements within their given societies. In this regard, Mohanty (2003) argues that:

...in any given piece of feminist analysis, women are characterised as a singular group on the basis of a shared oppression. What binds women together is a sociological notion of the 'sameness' of their oppression ... This results in an assumption of women as an always-already constituted group, one which has been labelled 'powerless,' 'exploited,' 'sexually harassed,' etc., by feminist scientific, economic, legal and sociological discourses....The focus is not on uncovering the material and ideological specificities that constitute a particular group of women as 'powerless' in a particular context. It is rather on finding a variety of cases of 'powerless' groups of women to prove the general point that women as a group are powerless (338).

While Mohanty (2003) has succeeded in challenging this rather poor perception of women, especially, from developing countries, to date, women continue to be portrayed as victims of male dominance and passive onlookers of development processes. The time has come to draw attention to the triumphs of women and how they initiate, pursue and direct change in their families, workplaces and communities. In the light of the above, this paper utilises different conceptions of empowerment to explore the motives and strategies that successful women from three different fields employ to empower other women in their localities and society at large. However, there is a dearth of literature on women's success stories in the African and Ghanaian contexts. This study, therefore, contributes to the existing body of knowledge on the ways through which women drive development issues in Ghana by highlighting the lived experiences about how some Ghanaian women have served as agents of change.

Adopting a social justice practice approach, the paper presents the lived experiences of a cross-section of successful Ghanaian women who are working in diverse ways to create spaces within which other women are empowered. Following the introduction is the review of the literature on the relationship between empowerment, agency and development. This is followed by the methodology adopted for the study after which the findings of the study are presented. The discussion of the findings and their implications for social work practice are then presented. 


\section{Conceptualising Empowerment}

It is believed that when people are empowered, they are able to participate in, contribute to, and benefit from growth (Eyben, Kabeer, and Cornwall 2008). Kabeer (1999) asserts that empowerment is about the process by which those who have been denied the ability to make strategic life choices acquire such ability. But empowerment is not an end in itself. What people do with the acquired ability; how they make choices to influence or enhance their own lives and those of others; and how this ability is manifested when acquired, are all important factors that are worth considering in the empowerment discourse.

According to the empowerment principles of Paulo Freire (1973) people are able to empower themselves when they acquire knowledge about the conditions that oppress them. Freire (1973) believed that when people think critically about their education, it would allow them to deeply examine their reality. He, therefore, advocated that through empowerment, people should be able to acquire needed skills, build confidence, and create opportunities for individual and collective action (Delp, Brown, and Domenzain 2005). With education - not necessarily formal, classroom education, but by giving access to information - people can empower themselves if they use the critical view afforded them. Thus, they can gain an understanding of existing social, economic, and political forces that affect their lives and take the necessary steps to change their circumstances.

The World Bank (2005), however, emphasises that empowerment is more than participation in decision making because 'it must also include the processes that lead people to perceive themselves as able and entitled to make decisions'. Therefore, seeking to empower women, in whatever form it would take - be it in giving them access to participate in decision making or to credit facilities, or even in income generating skills - without seeking to make fundamental changes to the cultural and structural barriers that exist in their societies becomes a fruitless exercise.

Karl (1995) explains that empowerment is a word widely used but seldom defined. To her, long before the word became popular, women were speaking about gaining control over their lives and particularly in the decisions that affect them in the home, the community, government and in the international development policies. She defines empowerment as "a process of awareness and capacity building leading to greater participation, to greater decisionmaking, power and control and to transformation action" (p. 13). Empowerment of women, therefore, is about creating awareness about oppressive conditions, helping women to acquire the necessary tools to overcome the oppression and building on that to transform their own lives. 
Empowerment should not be understood as one person or group giving power to another.

In an effort to conceptualise empowerment, Kabeer (1999) asserts that it is the process by which those who have been denied the ability to make choices acquire such ability. She explains that empowerment, therefore, entails a process of change, in that a person who hitherto did not have the ability to make critical life choices should experience the change that now affords him or her the ability to make such choices. In this regard, a person can be said to be empowered if he or she acquires or expands the ability to make strategic life choices within a context where they had been previously denied. Empowerment, therefore, cannot be reduced to a single aspect of process or outcome but rather, on how women are able to exercise choice, and the outcome always depends on the individual, class, time and space.

\section{Empowerment, Agency and Development}

Without a doubt, women's empowerment and agency are precursors to development. This has resulted in many governments and development agencies prioritising women's empowerment programs in national development projects (Cornwall and Anyidoho 2010). Sen (2001: 506) also draws linkages between development and freedom, arguing that "freedom is both the primary objective of development and its principal means". When people are free to make decisions about and pursue things which they consider to be of value to them without fear of retribution or violence, they are said to exercise their agency. Sustainable human agency is without a doubt the most powerful engine of development.

Since the early 1990s when governments around the world begun implementing what was known as the Washington Consensus, there has been an accompanying pursuit of the principles of human freedom and dignity, perhaps as an unspoken admission that without freedom and dignity, efforts at development will not succeed. However, as Kabeer (1999) points out, empowerment is not merely about giving power to a group of people who are otherwise disempowered, but is rather multidimensional. It involves both the personal and public aspects of women's lives: their sense of self-worth and social identity, as well as the ability to exercise agency within their given societies. It is after women have achieved these that any country can boast of attaining gender parity and empowering its women.

The government of Ghana admits in its Strategic Implementation Plan of the Ministry of Women and Children's Affairs (now Ministry of Gender, Children and Social Protection) that major sources of women's subordination in Ghana are "the social constructions of womanhood centred on reproductive roles which restrict women's access to productive resources 
such as credit, land, training and education, and also to decision-making processes" (Anyidoho and Manuh 2010, 268).

Rowlands (1995) asserts that empowerment should be about bringing people who are outside the decision-making process into it by putting a strong emphasis on access to political structures and formal decision-making. To become fully empowered, many women need to have the burden of productive and reproductive responsibilities reduced, access to higher and quality education and health expanded, have the expertise to make decisions on their sexual and reproductive health issues and effectively participate in the civic affairs of their societies. In addition to these, women also need access to credit and safety nets to be able to compete favourably with men and remove the unequal sources of power and ideologies that perpetuate women's subordination (see Kabeer 1997).

\section{Methodology}

The general target population for this study was successful Ghanaian women. However, selection of participants was restricted to the fields of academia, politics and trade. These three categories of fields were selected because they were either regarded as male dominated (in the cases of academia and politics) or had a large pool of women concentrated in this field (trade). All study participants were purposively selected based on the positions held in the fields from which they were selected.

In academia, female academic staff who occupy such senior positions as lecturers, heads of departments, schools and faculties, as well as senior administrative positions such as deans, provosts and vice-chancellors were selected while in politics, women in key government positions and heads of public institutions were selected. Women in trade consisted of entrepreneurs and exporters of goods as well as women who had businesses in more than one country. A total of ten women from each field were selected for in-depth interviews. These interviews focused on eliciting information from participants about their socio-demographic backgrounds, experiences while growing up, and how these experiences shaped their motives for seeking to empower other women. In addition, the strategies they employed while doing so were explored. All interviews were audiotaped with the permission of the participants.

The recorded in-depth interviews were transcribed, coded, and analysed thematically based on the objectives of the study. In doing so, the interviews were played and listened to several times to accurately capture the data which was later transcribed. By inductively analysing the data, dominant themes emerged devoid of the restraints imposed by structured methodologies (Thomas 2003). These emerging themes were compared 
across the different fields from which the participants were drawn, so identify linkages and commonalities as well as possible ideas that made the information more meaningful (Creswell 2009). The themes that were considered to be relevant to the objective of the study were used in the analysis and discussion of the findings. The most illustrative quotations were extracted to underscore arguments being put forward. Pseudonyms are used in place of participants' real names to protect their identity and ensure confidentiality.

\section{Profile of study participants}

A total of 30 women from three categories of professional fields were selected for the study. Ten women each from academia, politics and trade were interviewed. The youngest respondent was 28 years old and the oldest was 60 years. Two respondents were divorced, one was widowed and one was unmarried; the rest of the respondents were married. With the exception of two, all respondents had children.

Respondents from academia were selected based on their occupation of senior positions within their universities. Eight out of ten respondents were PhD holders, while the remaining two had Master's degrees. All ten of the respondents were heads of a units or had an administrative position.

With the respondents from politics, all ten of them had university degrees. Nine of the respondents were married with one divorced. Three of the respondents were members of parliament, five were either former ministers of state, heads of public offices as well as heads of national and nongovernmental organisations while two were leading members of political parties.

Study participants from trade came from a wide range of backgrounds but all ten of them were owners of their businesses. Five of the respondents from trade had university education, three had post-secondary education and two had secondary education. All ten respondents were married with children, except one who was married but had no children. Some respondents were service providers while others were entrepreneurs. One was a caterer with a well-established business in Kumasi and Accra, three were exporters of handmade crafts and members of the African Entrepreneurs Academy, one was the owner of a well-established hospital, two were fashion designers with businesses in Ghana and other African countries, two were owners of schools and one, a leader in the beauty industry in Ghana.

\section{Findings and Discussions}

The study aimed at exploring the motives and strategies successful Ghanaian women employ to empower other women. The findings revealed that there 
are three main motives that drive successful women to empower others. These are broadly categorised as altruistic, egoistic and reciprocal motives. In terms of strategies employed, they included mentoring, promoting femalefriendly work policies and pursuing community-related activities.

\section{Motivations for Influencing Change}

\section{Altruism}

Most of the participants reported that, they saw something in the other people for whom they acted as agents of change that made them want to help. Annie is an entrepreneur who has helped one of her employees to acquire a university education because she felt a strong desire to help the employee when she found out that the only reason the employee was working was because her parents could not afford to pay her fees. She indicated:

There was this lady who I initially employed as a cleaner, but something drew me to her so I started asking about her background. She told me she was working to save enough money to continue her education because her parents could not afford to pay her fees beyond the basic level. Of course, I felt inclined to help her and now she has a degree and is even planning to go for a master's.

In a similar vein, Boatemaa, head of a department in one university recounted how she helped to pay one of her students' fees and other financial obligations after she learnt of the difficulties the student was facing.

I had a student who was always withdrawn and appeared distracted in class so I asked her what the problem was. Initially she didn't want to open up about it but after some persistence from me, she told me of some serious financial challenges she was facing. I felt so moved by her story that I decided to pay her fees and also give her money for her upkeep until she completed her degree. She's working with one international NGO now and is doing quite well.

Oparebea indicated that she felt obligated to ensure that every house-help she engaged returned with some skill that would help her live an independent and empowered life. She related:

I feel that I have to ensure that I positively influence everybody that I come across and so whenever I live with a house help, I make sure that by the time she's going back to wherever she came from, she would have some skill that would help her live an independent and economically empowered life. I see it as my Christian duty, and I can count not less than ten girls who have lived with me so far.

Likewise, Mrs Mingle engages in altruistic acts because she was raised to always help people in need. According to her, while growing up, she was trained to offer a helping hand whenever she could. This training, she says, has inculcated in her a drive to always help others in any way she could. She however added that she preferred to help other women because she knows 
by helping a woman, she touches the lives of not only that woman but her whole family.

Over here, there are lots of people I've employed, but most of them are women. I think there are just about two men compared with over fifteen women who are here. I usually offer employment to the women because I know that once they get money, they want to pay their children's school fees and keep the rest for managing the homes, but the men will just go and booze (sic).

People behave and act in prosocial ways for very different reasons. At the core of prosociality is the concept of altruism (Smolenska and Reykowski 1992). Post (2002: 53) defines an altruist as "someone who does something for the other and for the other's sake, rather than as a means to self-promotion or internal well-being...". Batson (1994: 606), on the other hand, asserts that altruism has "the ultimate goal of increasing the welfare of one or more individuals other than oneself". Distinguishing between altruism, helping and self-sacrifice, Batson (1994) further clarified that the actions of an individual can be considered to be altruistic only if the actor intended to improve the wellbeing of the recipient.

For Serwaa, it was a matter of using her resources and influence as a Member of Parliament to mobilise women in the different districts within the constituency and equipping them with the skills to contest for district level elections.

For me, I'm very passionate about women contesting for, and winning the District Assembly elections. Once we get that, I believe we can change the whole constituency. But many women don't have the confidence and the support to also come out and contest, but by God's grace, I have the resources and links, so I use that influence to also help them.

Ella, who is a leader of a political party talks about how she goes from place to place giving talks and encouraging women to go after their dreams.

Any chance I get, I try to encourage women. If you call me to attend a programme, and I haven't already committed to something else, I'll definitely come. I think it's important for me to be doing this because you don't see women who are leaders of political parties in our side of the world. So I think there's a lot of work that we need to do, and I'm trying to tell women that, it is fine for somebody to give you something, but it's important and more effective if you get up and go after it yourself.

The narratives of the participants about their motives for acting altruistically indicate that they either felt empathetic towards the beneficiaries of their prosocial acts, or saw the beneficiaries as having something in common with them. This is in tandem with the arguments of Aron et al (1991) who have pointed to the fact that, people are likely to be altruistic towards others when they experience a sense of 'oneness' with that person or when they sense that 
the other person is part of their own identity (cited in Maner and Gailliot 2007).

\title{
Egoism
}

Batson, Ahmad and Tsang (2002) identify egoism as one of four motivations for community involvement. To these authors, "egoism is the most obvious motive for acting for the common good... (especially, where such) action either is instrumental to reaching the ultimate goal of self-benefit, or is an unintended consequence of reaching this goal" (434). Egoism has been identified to be fundamental to human nature, since people are more likely to help others in order to maximise their own self-benefits and avoid pain or cost (Gantt and Burton 2013; Hoffman 2000).

To the extent that the reasons some of the participants gave for working to empower other women also benefitted the participants in the long run, their actions and motivations are considered to be egoistic in nature. Jemma, a former minister and a member of parliament recounts that even though she had not initially planned to enter politics, it was when she went to work in a deprived community as a nurse that her dedication to the people got her nominated to become a government appointee.

\begin{abstract}
I was living in London but decided to come home and help my people. As a nurse, I was posted to a community where there were no lights and potable water but I didn't refuse. I went and worked hard in those communities. I worked there for over ten years, doing more than a nurse's work. So when this grassroots governance thing was introduced, the people themselves nominated me to represent them. I see that it was my work with this other community that ushered me into politics so I continue to do good to others, who knows what will come in the future?
\end{abstract}

Mansah, on the other hand, preferred to offer free training and employment to other women who often came to ask her help in meeting some financial obligation for their children. That way, such women would have skills, earn some income and meet their children's needs without having to come to her all the time.

There have been times that some women have approached me to ask for a loan to either pay their children's fees or send them to hospital. So what I did was to tell them that "why don't you come and train with me, I'll be paying you some little money while you help around here, and when you finish training, you can either work with me or go on to start your own business". Trust me, these women and I have not regretted this. The women are now economically empowered and are doing very well.

Some authors have argued that all prosocial behaviour is driven by egoistic motives, because actions that are intended to help a person in need may in actual fact be motivated by a desire to enhance one's own emotional state rather than a desire to enhance the welfare of the person in need (see Dovidio 
et al. 1991; Cialdini et al. 1987). A person would therefore work to alleviate the plight of another, not because $\mathrm{s} /$ he wants to seek the welfare of the one in need per se, but because in so doing, $\mathrm{s} /$ he is likely to increase some positive emotion or reduce some negative tension within him/herself.

Consistent with this assertion, Cathy who is involved with the youth of her church recounted that providing social support for the young people, knowing that some of them have no one to positively influence their lives gives her a sense of satisfaction and purpose. She indicated:

You see, most of these young people have nobody who would even say "you can do it" to them. So when I provide this pastoral care to them and help them to develop a positive outlook on life, it gives me a great sense of satisfaction.

Batson, Ahmad and Tsang (2002: 435), indicate that, although "people may get involved to see themselves - or be seen by others - as caring, concerned, responsible, good people. Pursuit of such side payments may provide great benefit to the community". And so long as their actions serve to empower other women and bring positive social change, then their egoistic motives need not be given negative connotations.

\section{Reciprocity}

Closely related to the concept of egoism is that of reciprocity as a motive for empowering others. Findings of this study indicate that, people tend to behave in prosocial ways to recompense for something which they received. Some participants in this study indicated a strong sense of obligation to reciprocate some action which they benefitted from, with the hopes that those towards whom they acted prosocially will continue paying it forward. This action of paying forward has been termed intergenerational reciprocity by Wade-Benzoni and Tost (2009). Some of the participants in this study felt that had it not been for that which they benefitted from in the past, they would not be in the positions they are enjoying now, and therefore, feel the need to help others, especially, their fellow women whom they consider to be disempowered. Hamdiyah, is a head of one of the country's public offices. Growing up, she was forced to drop out of school because her parents did not believe in educating the girl child and were not committed to ensuring that she went to school, even though she did not have to pay any fees. However, when she was nine years old, she was sent to serve as a house help to somebody who enrolled her in school and insisted that she went to school every day. This person also ensured that she kept up with her academic work, taking the pains to buy her books and giving her exercises at home. She related:

In my area, parents were more concerned about their sons' education than their daughters, so my parents didn't care whether I went to school or not, although it was free. It was only when I went to live with someone that she took my education so 
seriously. She would buy me books and make sure I do all my homework, plus the exercises she would give me at home. Honestly, I owe all that I am today to her... so now, whenever I go back home, I bring some girls with me so I can send them to school.

Hamdiyah's drive to help empower other girls (and women) from her community stems from her feeling of gratitude towards the person who turned her life around. It is argued that experiencing gratitude serves as a motivating factor for beneficiaries to repay their benefactors and to extend generosity to third parties (McCullough, Kimeldorf, and Cohen 2008). Conversely, Darkowa's conception of reciprocity is more rooted in the belief of doing unto others as she would want others to do unto her (Goodman 2000). Her core motivation for helping empower other women is because she feels that if she weren't empowered, she would have wished to have been empowered.

I always have this drive in me to help change other women's destinies. I am lucky that I've never at any point felt disempowered, but I think that if I were [not empowered] and nobody did anything to empower me, I would be very disappointed. We always want to wait for the government to initiate programmes and things like that, but as individuals, if we all contributed our quota, women will not be marginalised in any society.

Similar sentiments were shared by Ella, a leader of a political party who believes that it is time women worked to empower each other and not wait for government to empower anybody.

I believe that it is up to us women to create the spaces that will empower other women. We have been side-lined for far too long, and nobody will do it for us...so it is about time we got up to fight for our fellow women. We need to work in whatever way we can to ensure that every woman is empowered.

Darkowa and Ella's motives for reciprocity resonate with Goodman's (2000: 1068) model of moral reasoning, one of which is a principle-oriented ethic of justice. Goodman (2000) asserts that when using the principle-oriented ethic of justice, people make moral decisions based on the application of logical, abstract, and impartial rules or principles. As a result, they consider something to be unfair or unjust when it violates accepted standards, which often involve equal rights, equal opportunity, or role-related obligations or duties.

\section{Strategies for Causing Change}

\section{Mentoring}

Participants in this study, knowing and having enjoyed the benefits of mentoring relationships in their own careers have also sought to mentor other younger women. Elize is a 60-year old entrepreneur who has mentored others both her church and workplace. She takes it upon herself to counsel younger 
women to work and support their husbands in taking care of their children. As well, she counsels the younger nurses who work in the hospital she founded to learn what she terms 'the correct principles' in life. She believes this is part of her responsibilities as a 'mother' to the younger generation.

I always teach, in my church I teach...the women and the young ones. The adults I teach them; I teach the mothers how to work hard to support their husbands to look after the children. And also the student nurses, those nurses who come here, I teach them the correct principles to move in life.

Mansah is another entrepreneur who mentors her protégés to start their own businesses.

I have mentored a lot of women. I got one student here who I mentored for a while, and she decided to go to training college on her own. So I assisted her training. Now, she has completed University of Education and is in Germany. Currently I have a high school graduate whom I have started mentoring. I want to assist her to set up her own business.

Similarly, Lydia has mentored many of the students in her beauty and cosmetics training school and says she finds great joy in seeing some of her protégés who are doing well for themselves. She particularly makes reference to one of her students who has gone on to establish three beauty centres in Accra, although she (Lydia) has only one.

I'm proud of all my trainees, because each of them is doing well...but I am particularly proud of Mary because I took her as my daughter and mentored her, and now she has three branches of her parlour in Accra. I'm always happy to see her doing so well.

Mentoring has been identified as an important component in women's career advancement and comprises both career and psychosocial support (Tharenou 2005). Career support entails sponsoring, coaching, providing challenging assignments, exposure and visibility in organisations while psychosocial support would involve friendship and acceptance, counselling, enhancing the protégé's self-efficacy and acting as role models (Allen et al. 2004, Wanberg, Welsh and Hezlett 2003). Career support mentoring is aimed at facilitating the protégé's advancement within an organisation while psychosocial mentoring is geared towards the protégé's personal growth and professional development (Ragins and Cotton 1999).

\section{Community-related activities}

It has been argued that women leaders' experiences and practice, particularly outside their business and commercial environments, are neither well documented nor analysed, nor are they reflected in current leadership theory (Elliott and Stead 2008). Nonetheless, Bond et al (2008) argue that although women have largely been absent from many formal, public, and civic arenas, 
they have been more visible in informal local leadership roles, as evidenced in grassroots neighbourhood and community movements.

When women lead or initiate community-related activities and programmes, they pursue those that are of a broad nature, comprehensive and will respond to the needs of other women, children and families (Gittell et al 2000). Consistent with this, findings of this study suggest that successful women in Ghana are actively engaged in community-related activities that help to promote the cause of other women. These activities are either related or not related to their professional activities per se. Annie, a respondent who is a member of the Rotary club, sees her role in the activities of the club as a contribution towards easing the burden on other women and also promoting good health in children.

I am a member of the Rotary club, and through that I have done a lot of community related activities. Some of these activities and projects may not be targeted at women per se, but in the long run, they benefit women and ease the burden on them. For instance if we do a community water project, our aim is to provide that community with clean, drinking water, but it eases the burden on women travelling long distances to fetch water, and also ensures that their children don't get sick frequently from water-related diseases. We can also talk about polio immunisation, library projects and a whole lot more.

Margie, who entered into an entrepreneurial competition and won an award of $\$ 25,000$ decided to use the money to train other women all over the country in income-generating skills. She then helped such women to form cooperatives and export their products through her company. She also considers this to be her widow's mite in helping to develop the country.

I recently won an award of $\$ 25,000$ for a contest I participated in, and I used the money to go round the country, training women on adding value to an indigenous product. I travelled from Accra to Wa, and in each of these places, I look for that thing within the community that we can add value to and export, and I trained the women in doing these things.

Gittell et al (2000) also suggest that women are deeply committed, community-based leaders who foster community participation and use a collaborative approach to create social change. Mrs Mingle confirmed this when she also talked about her commitment to the community in which she lives, where she leads to bring social amenities and attention of government to the community. This action of hers has endeared her to the community members that, they have been impressing upon her to contest as an Assembly woman, since they believe that, in government, she will be better placed to bring development to the area. She relates:

People have been asking me to contest for Assembly woman because of the way I'm committed to this community. I take active part in everything we do here as a 
community, and if there is something the community needs, you can be sure that I'll be in the lead.

Bond et al (2008) posit that women's community engagement in turn contributes to their own development, as women involved in their communities report achieving more open-mindedness about people and ideas, a more positive self-image, and increased connections with people and community, among other self-developmental benefits. In light of this, it can be argued that success and community engagement in women have a reciprocal relationship. Beyond the self-developmental benefits though, for certain groups of women such as politicians, engaging in community activities serves as a platform for them to either maintain or elevate their professional status. Thus, it is important for successful women to engage more in community-related activities.

\section{Female-friendly work policies}

Study participants who were in management positions also talked about instituting female-friendly policies in their workplaces. Women who are in leadership positions have been found to be more responsive to other women's needs as they prioritise and take leading roles in formulating policies with women's perspective in mind (Zakuan 2010). As Ella recounted, she sought to institute female-friendly policies in her workplace when she became the Director General of a public institution. She was the first female director, and was disappointed that even in middle level management, there were very few women there. Recognising the problem to be more human capital-based, she arranged with one public institution based in Accra to start a training course for all women who had the desire and the qualification to pursue higher education. She asserts:

When I got there, I realised that there was only one woman in middle management. Everybody else was below management, and when you looked at the people coming up for promotion, it was always one woman here, one woman there (sic). So I started a training course that all the female staff with the right qualification should go. After the course, they were eligible for promotion into management.

Laura heads a centre in a public university and reported that since she became head of the centre, she has instituted a policy of giving preference to a qualified woman over a man. Also in the centre's admission policies, they ensure that at least forty percent of all students admitted into their master's programme are females. She recounts:

This centre is seriously female-gender biased; we have a policy that if two people who are equally qualified apply for a job and one is a female, we would give preference to her and when we admit students, we always strive to have at least a forty-sixty balance since the beginning of our master's programme. 
Cathy also reports promoting flexible office hours and space for the female members of staff in her department, although most are done on an unofficial basis. She notes that in addition to following the legal statutes that allow new mothers to close earlier than their colleagues, when there is the need, mothers can ask for permission to send their children to the hospital without it counting as a day off from work, pick their children from school and attend parent-teacher meetings. She indicates:

We are quite flexible here. We understand that women need some extra time, so if a
woman returns from maternity leave, she closes earlier than her colleagues, then if
someone needs to take a sick child to the hospital, attend PTA meeting or something
of the sort, they can always ask permission and another person will stand in for her.
Some of the mothers also pick their children up from school and bring them to the
office until they close. These are all some of the things we allow so that women can
have the peace of mind to focus on their work.

A strong correlation has been found between worker-friendly policies and employee retention, employee satisfaction, and employee productivity (Hoyman and Duer 2004). It is, therefore, important to encourage, promote and pursue female-friendly work policies in order to prevent the glass ceiling phenomenon and reduce time constraints on working women.

\section{Conclusion and implications}

This paper has highlighted the different strategies that successful women in Ghana employ to empower other people in their families, workplaces and communities. These strategies included mentoring, engaging in communityrelated activities and initiating or pursuing female-friendly work policies. Some reasons that underlie their drive to influence change were categorised broadly as altruistic, egoistic or reciprocal. Successful women were more likely to act on behalf of others when they experienced a sense of oneness with the other person or felt empathetic towards the other. They also felt motivated to help others when they foresaw some benefit that could come to them as a result of their helping behaviour, or when they felt the need to pay back something which they had received.

\section{References}

Allen, T. D., Eby, L. T., Poteet, M. L., Lentz, E. and Lima, L. (2004) Career benefits associated with mentoring for protégés: A meta-analysis. Journal of Applied Psychology, 89, 127-36.

Anyidoho, N. A. and Manuh, T. (2010) Discourses on women's empowerment in Ghana. Development 53(2), 267-273.

Batliwala, S. (2007) Taking the power out of empowerment-an experiential account. Development in Practice 17(4-5), 557-565. 
Batson, C. D. (1994) Why act for the public good? Four answers. Personality and Social Psychology Bulletin, 20, 603-610.

Batson C. D., Ahmad, N. and Tsang, J. (2002) Four Motives for Community Involvement. Journal of Social Issues, 58(3) 429-445

Bond, L. A., Holmes, T. R., Byrne, C., Babchuck, L. and Kirton-Robbins, S. (2008) Movers and shakers: How and why women become and remain engaged in community leadership. Psychology of Women Quarterly, 32, 48-64.

Cornwall, A. and Anyidoho, N. A. (2010) Introduction: women's empowerment: contentions and contestations. Development 53(2), 144-149.

Creswell, J. W. (2009) Research Design: qualitative, quantitative, and mixed methods approaches. 3rd edn. Thousand Oaks: Sage.

Delp, L., Brown, M. and Domenzain, A. (2005) Fostering youth leadership to address workplace and community environmental health issues: a university-school-community partnership. Health Promotion Practice 6(3) 27085. doi: $10.1177 / 1524839904266515$.

Dovidio, J. F., Piliavin, J. A., Gaertner, S. L., Schroeder, D. A. and Clark, R. D. (1991) The arousal/cost-reward model and the process of intervention: A review of the evidence. In M. S. Clark (ed.) Prosocial behavior. Review of personality and social psychology. Thousand Oaks, CA, US: Sage Publications, $12,86-118$.

Elliott, C. and Stead, V. (2008) Understanding Learning from Leading Women's Experience: Towards a Sociological Understanding. Leadership.4(2), 159-180.

Eyben, R., Kabeer, N. and Cornwall, A. (2008) Conceptualising empowerment and the implications for pro-poor growth: a paper for the DAC Poverty Network. Report to DAC POVNET on empowerment.

Freire, P. (1973) Extension or communication. New York: McGraw.

Gantt, E. E and Burton, J. (2013) Egoism, Altruism, and the Ethical Foundations of Personhood. Journal of Humanistic Psychology. 53, 438-460.

Gittell, M., Ortega-Bustamante, I. and Steffy, T. (2000) Social Capital and Social Change: Women's Community Activism. Urban Affairs Review, 36(2), $123-147$.

Goodman, D. J. (2000) Motivating People from Privileged Groups to Support Social Justice. Teachers College Record. 102(6), 1061-1085. 
Hoffman, M. L. (2000) Empathy and moral development: Implications for caring and justice. Cambridge, England: Cambridge University Press.

Hoyman, M., and Duer, H. (2004) A Typology of Workplace Policies: Worker Friendly vs. Family Friendly? Review of Public Personnel Administration. 24(2), 113-132.

Kabeer, N. (1999) Resources, agency, achievements: Reflections on the measurement of women's empowerment. Development and Change 30 (3) 435464.

Karl, M. (1995) Women and Empowerment: Participation and Decision Making. London: Zed Books.

Maner, J. K. and Gailliot, M. T. (2007) Altruism and egoism: Prosocial motivations for helping depend on relationship context. European Journal of Social Psychology 37, 347-358.

McCullough, M. E., Kimeldorf, M. B. and Cohen, A. D. (2008) An Adaptation for Altruism: The Social Causes, Social Effects, and Social Evolution of Gratitude. Current Directions in Psychological Science, 17(4), 281-285.

Mohanty, C. T. (2003) 'Under western eyes' revisited: feminist solidarity through anticapitalist struggles. Signs 28(2), 499-535.

Post, S. (2002) The tradition of agape. In S. Post, L. Underwood, J. Schloss, and W. Hurlbut (eds.) Altruism and altruistic love: Science, philosophy and religion in dialogue. New York: Oxford University Press, pp. 51-64.

Ragins, B. R. and Cotton, J. L. (1999) Mentor Functions and Outcomes: A comparison of Men and Women in Formal and Informal Mentoring Relationships. Journal of Applied Psychology, 84(4), 529-550.

Rowlands, Jo (1995) Empowerment examined. Development in Practice 5(2) 101-107.

Sen, Amartya (2001) Development as freedom: Oxford Paperbacks.

Tharenou, P. (2005) Does Mentor Support Increase Women's Career Advancement More than Men's? The Differential Effects of Career and Psychosocial Support. Australian Journal of Management. 30(1), 77-109.

Wade-Benzoni, K. A. and Tost, L. P. (2009) The Egoism and Altruism of Intergenerational Behavior. Personality and Social Psychology Review, 13(3), 165-193. 
Wanberg, C.R., Welsh, E.T. and Hezlett, S.A. (2003) Mentoring research: A review and dynamic process model. Research in Personnel and Human Resources Management. 22, 39-124.

Zakuan, U. A. A. (2010) Women in the Malaysian parliament: do they matter? Intellectual Discourse, 18(2), 283-322. 